\title{
MAP2K3 wt Allele
}

National Cancer Institute

\section{Source}

National Cancer Institute. MAP2K3 wt Allele. NCI Thesaurus. Code C125165.

Human MAP2K3 wild-type allele is located in the vicinity of $17 q 11.2$ and is approximately

$31 \mathrm{~kb}$ in length. This allele, which encodes dual specificity mitogen-activated protein kinase kinase 3 protein, plays a role in signal transduction. 